\section{Amgen scores a knockout}

\section{Washington}

DESPITE expectations to the contrary, Amgen Inc. has emerged as the outright winner in its bitter dispute with Genetics Institute over US patent rights to erythropoietin (EPO). The US Court of Appeals for the Federal Circuit ruled that key claims in Amgen's patent were valid and enforceable and declared Genetics Institute's patent invalid.

The decision guarantees a market monopoly for Amgen. As a result, Genetics Institute will be unable to sell its version of EPO in the United States through its licensee Chugai Pharmaceutical Co. Ltd. EPO, which stimulates the growth of red blood cells, is proving to be a valuable therapy for patients on kidney dialysis, who often develop anaemia. AIDS patients with anaemia may also benefit from EPO.

News of the court decision took Wall Street by surprise and sent the company's shares up 12 per cent to close at $\$ 113$. Just three weeks before the court's EPO decision, Amgen won US Food and Drug Administration (FDA) approval to market granulocyte-colony stimulating factor (GCSF), another biotechnology drug. The colony stimulating factor enhances white blood cell production and is expected to find wide use among cancer patients and others who are suffering from immune deficiency.

Gordon Binder, Amgen's chairman and chief executive officer, stated that the court decision in the EPO case "vindicates our position completely". He believes that the ruling will encourage original research and development by reassuring the pioneers within the biotechnology industry that they can expect adequate patent protection for their inventions. Gabriel Schmergel, president and chief executive officer of Genetics Institute said "we are very disappointed with the decision" but would not indicate whether the company will take any further action.

The protracted patent dispute spanned three-and-a-half years and concerns conflicting US patent claims to EPO, a natural protein that is made in the kidney. In June 1989, the FDA approved Epogen, Amgen's genetically engineered version of EPO, for the treatment of anaemia in patients with chronic kidney failure. Estimated US sales of Epogen for 1992 are expected to top $\$ 400$ million. Along with marketing approval, FDA awarded Epogen "orphan drug" status under an act that provides companies with incentives, including a guaranteed sevenyear market monopoly, to develop drugs to treat rare diseases.

At the time, both Amgen and Genetics Institute held EPO patents. Amgen won its patent for discovery of the gene that produces EPO, whereas the Genetics Institute patent was awarded for isolation of the EPO molecule from human urine, as well as for preparation of a recombinant version panies to cross-license. NATURAL HISTORY MUSEUM of the protein. A court in Massachusetts, which heard the patent case in 1989 , validated the central claims in both Amgen's and Genetics Institute's patents but declared that they were mutually infringing (see Nature 342, 846; 1989). Observers expected that the appeals court in Washington, DC, would uphold the Massachusetts ruling and that the continued stalemate would force the com-

Although the federal appeals court affirmed Amgen's patent as valid and enforceable, Genetics Institute was dealt a severe and unexpected blow when the court struck down its patent claims to EPO. The court ruled that Genetics Institute and its licensee, Chugai, had failed to show that they had purified EPO, whether recombinant or urinary-derived, with the claimed specific activity using the methods disclosed in the patent. Genetics Institute had argued that its

\section{Innovative ecology exhibits}

\section{IMAGE UNAVAILABLE FOR COPYRIGHT REASONS}

Leafy environment - shrinking down to 8,000 times smaller, visitors to the ecology exhibition can take a tour around the 'inside' of a leaf.

A TOWERING glass greenhouse inside the Natural History Museum in London sets the scene for an impressive yet controversial permanent exhibition on ecology that opened on 7 March. It is the first of five new exhibitions scheduled to open over the next few years and sponsored by the museum's independent Development Trust Appeal. The exhibition marks an important shift away from government funding, but the inhouse team largely responsible for the ex- claim to EPO was stronger because Edward F. Fritsch of Genetics Institute first conceived the strategy to identify and isolate the EPO gene back in 1981, even though FuKuen Lin of Amgen was first to accomplish this goal in September 1983, followed by Fritsch eight months later. The appeals court (hitsch "had no 1981 because he did not know the sequence the gene encoding EPO."

Peter Drake, stock analyst with Vector Securities, paid tribute to Amgen's management team, who he said had the long-term vision, energy and commitment to defend its patent position "in the face of significant pressure from Wall Street and other circles to the patent dispute] behind them". Amgen is now in the enviable position of having "two of the che biotechnology industry", says Drake, who estimates that the company will have $\$ 1,000$ million in sales by 1993 .

Diane Gershon more of a conception in 1983 than he did in quence of the museum's cost-cutting 1990-91 corporate plan. The visually exciting exhibition, which was a result of careful market research, has not met with universal praise, however. Its interactive video and spectacular effects have largely replaced traditional exhibits, something scribed as "appalling".

Henry Gee, London hibition is to be disbanded as a consethat a curator at another UK museum de- 